\begin{tabular}{|l|l|}
\hline SITAS & JAGROS Journal of Agrotechnonogy and Science \\
& Jurnal Agroteknologi dan sains \\
Fakultas Pertanian, Universitas Garut \\
P ISSN : 2775-0485, E ISSN : 2548-7752
\end{tabular}

\title{
Pengaruh Berbagai Jenis Pupuk Kandang Dan Frekuensi Penyiangan Terhadap Pertumbuhan Dan Hasil Tanaman Selada Keriting (Lactuca sativa L.)
}

\author{
The Influence of Different Types of Manure and Weeding Frequency on the Growth and Yield \\ of Curly Lettuce (Lactuca sativa $\mathbf{L}$. \\ Oryza Affandina Sani ${ }^{1}$, Hanny Hidayati Nafi'ah ${ }^{2}$, Novriza Satia ${ }^{2}$ \\ Prodi Agroteknologi, Fakultas Pertanian, Univesitas Garut \\ Jalan Raya Samarang Nomor 52.A, Garut. \\ e-mail : affandinaoryza@gmail.com
}

\begin{abstract}
Manure is a fertilizer that is widely used in organic agriculture. The purpose of this study was to determine whether there was a best combination of manure used and weeding frequency on plant growth and yields. The research was done in Cimaragas, Cilawu District, Garut Regency from August to September 2020. The research used an experimental method with factorial randomized block design (FRBD) consisted of 2 treatment factors with 3 replications, namely: First treatment (Types of Manure) consisted of goat manure $\left(\mathrm{k}_{1}\right)$, cow manure $\left(\mathrm{k}_{2}\right)$, chicken manure $\left(\mathrm{k}_{3}\right)$, and NPK fertilizer $\left(\mathrm{k}_{0}\right)$ as control. Second treatment (Weeding frequency) consisted of without weeding $\left(\mathrm{p}_{0}\right), 2$ times of weeding $\left(\mathrm{p}_{1}\right)$, and 4 times of weeding $\left(\mathrm{p}_{2}\right)$. The results showed that there was an interaction on the observation parameters of dry weight and leaf area of the plant. The combination that gives the best influence was cow manure with 2 times of weeding.
\end{abstract}

Keyword: lettuce, manure, weeding

Abstrak

Pupuk kandang merupakan pupuk yang banyak digunakan dalam pertanian organik. Tujuan dari penelitian ini adalah untuk mengetahui apakah ada kombinasi pupuk kandang yang digunakan dan frekuensi penyiangan yang terbaik terhadap pertumbuhan dan hasil tanaman. Penelitian dilaksanakan di Cimaragas, Kecamatan Cilawu, Kabupaten Garut pada bulan Agustus sampai dengan September 2020. Penelitian ini menggunakan metode eksperimen dengan Rancangan Acak Kelompok (RAK) faktorial terdiri dari 2 faktor perlakuan dengan 3 ulangan, yaitu: Perlakuan pertama (Jenis Pupuk Kandang) terdiri dari kotoran kambing (k1), kotoran sapi (k2), kotoran ayam (k3), dan pupuk NPK (k0) sebagai kontrol. Perlakuan kedua (Frekuensi penyiangan) terdiri dari tanpa penyiangan (p0), 2 kali penyiangan (p1), dan 4 kali penyiangan (p2). Hasil penelitian menunjukkan bahwa terdapat interaksi pada parameter pengamatan berat kering dan luas daun tanaman. Kombinasi yang memberikan pengaruh terbaik adalah pupuk kandang sapi dengan 2 kali penyiangan.

Kata kunci: selada, pupuk kandang, penyiangan 


\section{Pendahuluan}

Permintaan sayuran selada keriting yang tinggi baik dari pasar domestik ataupun pasar luar negeri menyebabkan sayuran hortikultura ini memiliki nilai ekonomi yang tinggi. Berdasarkan data Badan Pusat Statistik (2017) menyatakan produksi tanaman selada keriting di Indonesia dari tahun 2015 sampai 2017 adalah sebesar 600.200 ton, 601.204 ton dan 627.611 ton. Produksi selada pada tahun 2017 meningkat jauh sebesar 26.407 ton, namun umumnya produksi selada di Indonesia tidak lepas dari penggunaan pupuk sintetis. Dampak negatif dari pupuk anorganik dapat diminimalisir, salah satu caranya adalah dengan mengembangkan pertanian organik yang ramah lingkungan dengan menggunakan pupuk organik seperti pupuk kandang (Devani, 2012).

Pupuk kandang dapat membantu penyerapan air hujan, meningkatkan kemampuan tanah untuk mengikat air, mengurangi erosi, membuat tanah lebih subur, gembur dan mudah diolah, memperbaiki struktur tanah, dan menambah kesuburan tanaman, serta pemberiannya tidak meninggalkan residu pada hasil panen serta tidak mencemari lingkungan (Abrianto, 2011).

Permasalah pada penanaman selada keriting yang dihadapi di lahan selain penggunaan pupuk sintetis adalah adanya gangguan gulma. Gulma dapat menurunkan kualitas maupun kuantitas hasil pertanaman dengan cara berkompetisi dengan tanaman budidaya untuk mendapatkan unsur hara, cahaya, air, $\mathrm{CO}_{2}$, dan ruang tumbuh (Hendrival dkk., 2004). Merujuk pada uraian diatas, maka penelitian ini bertujuan untuk menguji pengaruh penggunaan jenis pupuk kandang dengan frekuensi penyiangan tertentu terhadap pertumbuhan dan hasil tanaman selada keriting.

\section{Meodologi}

Penelitian dilaksanakan di Cimaragas, Kecamatan Cilawu dengan ketinggian \pm 760 mdpl, ketinggian tempat diukur penggunakan aplikasi accurate altimeter. Penelitian ini dimulai pada bulan Agustus 2020 sampai dengan September 2020. Penelitian ini menggunakan Rancangan Acak Kelompok Faktorial (RAKF) dengan 2 faktor perlakuan. Faktor pertama adalah jenis pupuk kandang $(\mathrm{K})$, yaitu : Kontrol NPK $\left(\mathrm{k}_{0}\right)$, pupuk kandang kambing 20 ton $\mathrm{ha}^{-1}\left(\mathrm{k}_{1}\right)$, pupuk kandang sapi 30 ton ha ${ }^{-1}\left(\mathrm{k}_{2}\right)$, dan pupuk kandang ayam 20 ton $\mathrm{ha}^{-1}\left(\mathrm{k}_{3}\right)$. Faktor kedua yaitu perlakuan frekuensi penyiangan $(\mathrm{P})$, yaitu: $\left(\mathrm{p}_{0}\right)$ Tanpa penyiangan, 2 kali penyiangan $\left(\mathrm{p}_{1}\right)$ dan 4 kali penyiangan $\left(\mathrm{p}_{2}\right)$.

Pengamatan yang dilakukan meliputi tinggi tanaman, jumlah daun, luas daun, bobot segar tanaman, bobot segar tanaman per plot, dan bobot kering tanaman. Data yang diperoleh akan dianalisis menggunakan analisis sidik ragam (ANOVA) RAK faktorial lalu di uji menggunakan uji beda nyata $\mathrm{F}$ pada taraf $5 \%$ dengan kaidah keputusan jika $\mathrm{F}$ hitung lebih besar dari F tabel maka perlakuan dilanjutkan dengan uji Duncan Multiple Range Test (DMRT) taraf $5 \%$. 


\section{Hasil Penelitian}

\section{Tinggi Tanaman}

Hasil analisis ragam pada tabel 1 menunjukkan tidak terjadi interaksi antara jenis pupuk kandang dan frekuensi penyiangan, tetapi terdapat perbedaan nyata pada faktor jenis pupuk kandang. Secara keseluruhan perlakuan pupuk kandang sapi memberikan hasil terbaik. diduga ketersediaan hara dan air yang cukup akan mendukung pertumbuhan tanaman, sedangkan kekurangan unsur hara dan air dapat menghambat pertumbuhan tanaman dan menyebabkan tanaman kerdil.

Tabel 1. Tinggi Tanaman $(\mathrm{cm})$

\begin{tabular}{|c|c|c|c|c|c|c|c|}
\hline \multicolumn{2}{|c|}{ PERLAKUAN } & $7 \mathrm{HST}$ & 14 HST & $21 \mathrm{HST}$ & $28 \mathrm{HST}$ & $35 \mathrm{HST}$ & $42 \mathrm{HST}$ \\
\hline $\mathrm{k}_{0}$ & Pupuk NPK & $2,66 \mathrm{a}$ & $3,36 \mathrm{a}$ & $5,35 \mathrm{a}$ & $9,86 \mathrm{a}$ & $14,06 \mathrm{a}$ & $18,32 \mathrm{a}$ \\
\hline $\mathrm{k}_{1}$ & $\begin{array}{l}\text { Pupuk Kandang } \\
\text { Kambing }\end{array}$ & $2,88 \mathrm{a}$ & $3,30 \mathrm{a}$ & $6,97 \mathrm{~b}$ & $12,41 \mathrm{~b}$ & $17,39 \mathrm{~b}$ & $22,05 \mathrm{ab}$ \\
\hline $\mathrm{k}_{2}$ & $\begin{array}{l}\text { Pupuk Kandang } \\
\text { Sapi }\end{array}$ & $3,11 \mathrm{a}$ & $4,31 \mathrm{~b}$ & $9,27 \mathrm{c}$ & $15,41 \mathrm{c}$ & $21,13 \mathrm{c}$ & $26,76 \mathrm{~b}$ \\
\hline $\mathrm{k}_{3}$ & $\begin{array}{l}\text { Pupuk Kandang } \\
\text { Ayam }\end{array}$ & $3,00 \mathrm{a}$ & $3,45 \mathrm{a}$ & $4,69 \mathrm{a}$ & $9,69 \mathrm{a}$ & $14,28 \mathrm{a}$ & $18,73 \mathrm{a}$ \\
\hline $\mathrm{p}_{0}$ & $\begin{array}{l}\text { Tanpa } \\
\text { Penyiangan }\end{array}$ & $2,87 \mathrm{a}$ & $3,54 \mathrm{a}$ & $6,54 \mathrm{a}$ & $11,50 \mathrm{a}$ & 16,39 a & $21,05 \mathrm{a}$ \\
\hline $\mathrm{p}_{1}$ & $\begin{array}{l}2 \text { kali } \\
\text { Penyiangan }\end{array}$ & $3,12 \mathrm{a}$ & $3,79 \mathrm{a}$ & 6,79 a & $12,24 \mathrm{a}$ & $17,67 \mathrm{a}$ & $22,70 \mathrm{a}$ \\
\hline $\mathrm{p}_{2}$ & $\begin{array}{l}4 \text { kali } \\
\text { Penyiangan }\end{array}$ & $2,75 \mathrm{a}$ & $3,49 \mathrm{a}$ & $6,38 \mathrm{a}$ & $11,79 \mathrm{a}$ & $16,08 \mathrm{a}$ & $20,64 \mathrm{a}$ \\
\hline
\end{tabular}

Keterangan: Angka yang diikuti huruf yang sama tidak berbeda nyata menurut uji DMRT taraf $5 \%$.

Bila dibandingkan tinggi tanaman pada perlakuan pupuk kandang sapi, nilai rerata tinggi tanaman menunjukkan perbedaan nilai yang signifikan, ini dapat disebabkan oleh penggunaan pupuk dengan dosis yang lebih tinggi dibandingkan dengan perlakuan pupuk kandang lainnya yaitu sebanyak 30 ton/Ha. Hal ini memperjelas bahwa pertumbuhan tanaman selada sangat dipengaruhi oleh tingkat ketersediaan unsur nitrogen $(\mathrm{N})$ yang pada masing - masing pupuk kandang memiliki nilai yang relatif sama maka perlakuan pupuk kandang sapi memiliki unsur $\mathrm{N}$ yang lebih tinggi dibandingkan dengan perlakuan pupuk kandang lainnya.

\section{Jumlah Daun}

Hasil analisis pada tabel 2 mennjuknan tidak terjadi interaksi antara jenis pupuk kandang dan frekuensi penyiangan, tetapi secara mandiri perlakan pupuk kandang sapi dengan 2 kali penyiangan memberikan hasil yang signifikan dibandingkan perlakan 
lainnya. Hal ini diduga karena tinggi tanaman berkaitan dengan jumlah daun tanaman. Daun tanaman selada terletak pada buku-buku batang semu maka semakin tinggi batang selada semakin banyak juga jumlah daun.

Tabel 2. Jumlah Daun

\begin{tabular}{|c|c|c|c|c|c|c|c|}
\hline \multicolumn{2}{|c|}{ PERLAKUAN } & $7 \mathrm{HST}$ & $14 \mathrm{HST}$ & $21 \mathrm{HST}$ & $28 \mathrm{HST}$ & 35 HST & $42 \mathrm{HST}$ \\
\hline $\mathrm{k}_{0}$ & Pupuk NPK & $1,43 \mathrm{a}$ & $1,78 \mathrm{~b}$ & $2,15 \mathrm{a}$ & $7,33 \mathrm{a}$ & $9,36 \mathrm{a}$ & $14,13 \mathrm{a}$ \\
\hline $\mathrm{k}_{1}$ & $\begin{array}{l}\text { Pupuk Kandang } \\
\text { Kambing }\end{array}$ & $1,48 \mathrm{a}$ & 1,86 bc & $2,35 \mathrm{~b}$ & $8,49 \mathrm{~b}$ & $12,02 \mathrm{~b}$ & $20,35 \mathrm{~b}$ \\
\hline $\mathrm{k}_{2}$ & $\begin{array}{l}\text { Pupuk Kandang } \\
\text { Sapi }\end{array}$ & $1,66 \mathrm{~b}$ & $1,95 \mathrm{c}$ & $2,56 \mathrm{c}$ & $11,58 \mathrm{c}$ & $16,71 \mathrm{c}$ & $25,29 \mathrm{c}$ \\
\hline $\mathrm{k}_{3}$ & $\begin{array}{l}\text { Pupuk Kandang } \\
\text { Ayam }\end{array}$ & $1,38 \mathrm{a}$ & $1,62 \mathrm{a}$ & $2,06 \mathrm{a}$ & $7,16 \mathrm{a}$ & $9,07 \mathrm{a}$ & $15,78 \mathrm{a}$ \\
\hline $\mathrm{p}_{0}$ & $\begin{array}{l}\text { Tanpa } \\
\text { Penyiangan }\end{array}$ & $1,54 \mathrm{a}$ & $1,83 \mathrm{a}$ & $2,27 \mathrm{a}$ & $8,01 \mathrm{a}$ & $10,87 \mathrm{a}$ & $17,90 \mathrm{a}$ \\
\hline $\mathrm{p}_{1}$ & $\begin{array}{l}2 \text { kali } \\
\text { Penyiangan }\end{array}$ & $1,45 \mathrm{a}$ & $1,79 \mathrm{a}$ & $2,29 \mathrm{a}$ & $9,06 \mathrm{~b}$ & $12,78 \mathrm{a}$ & $21,07 \mathrm{~b}$ \\
\hline $\mathrm{p}_{2}$ & $\begin{array}{l}4 \text { kali } \\
\text { Penyiangan }\end{array}$ & $1,48 \mathrm{a}$ & $1,78 \mathrm{a}$ & $2,28 \mathrm{a}$ & $8,85 \mathrm{ab}$ & $11,72 \mathrm{a}$ & $17,7 \mathrm{a}$ \\
\hline
\end{tabular}

Keterangan: Angka yang diikuti huruf yang sama tidak berbeda nyata menurut uji DMRT taraf $5 \%$

Wijaya (2008), menyatakan bahwa unsur nitrogen adalah unsur makro essesial yang berperan utama sebagai penyusun komponen tubuh tumbuhan seperti protein, enzim, hormon dan klorofil. Yusrianti (2012) menyatakan bahwa semakin tinggi unsur hara yang diberikan, maka unsur hara tersebut akan dimanfaatkan untuk proses fisiologi tanaman seperti jumlah daun dan luas daun.

\section{Luas Daun}

Hasil analisis pada tabel 3 menunjukkan terjadi interaksi antara jenis pupuk kandang dan frekuensi penyiangan pada parameter luas daun dimana hasil terbaik didapat pada kombinasi perlakuan pupuk kandang sapi dengan 2 kali penyiangan.

Hal ini diduga karena penyerapan faktor tumbuh dan unsur hara yang baik membuat tanaman dapat berfotosintesis secara optimal serta minimalnya persaingan dengan gulma membuat tanaman tumbuh dengan baik sehingga hasil pengamatan luas daun menjadi lebih tinggi.

Tabel 3. Luas Daun (gram)

Jenis Pupuk Kandang Frekuensi Penyiangan




\begin{tabular}{cccc} 
& $\mathrm{p}_{0}$ & $\mathrm{p}_{1}$ & $\mathrm{p}_{2}$ \\
& (Tanpa Penyiangan) & $(2$ kali Penyiangan) & (4 kali Penyiangan) \\
\hline $\mathrm{k}_{0}$ (Pupuk NPK) & $163,20 \mathrm{a}$ & $120,32 \mathrm{a}$ & $178,27 \mathrm{a}$ \\
$\mathrm{k}_{1}$ (Pupuk Kandang & $\mathrm{A}$ & $\mathrm{A}$ & $\mathrm{A}$ \\
Kambing) & $204,52 \mathrm{a}$ & $373,18 \mathrm{~b}$ & $352,91 \mathrm{~b}$ \\
$\mathrm{k}_{2}$ (Pupuk Kandang & $\mathrm{A}$ & $\mathrm{B}$ & $\mathrm{B}$ \\
Sapi) & $220,63 \mathrm{a}$ & $600,31 \mathrm{c}$ & $399,16 \mathrm{~b}$ \\
$\mathrm{k}_{3}$ (Pupuk Kandang & $\mathrm{A}$ & $\mathrm{C}$ & $\mathrm{B}$ \\
Ayam) & $166,06 \mathrm{a}$ & $160,08 \mathrm{a}$ & $146,04 \mathrm{a}$ \\
\hline
\end{tabular}

Keterangan: Angka rata-rata yang diikuti huruf kecil yang sama secara vertikal dan huruf besar yang sama secara horizontal tidak berbeda nyata menurut uji DMRT taraf $5 \%$.

\section{Bobot Segar Tanaman}

Tidak terjadi interaksi antara jenis pupuk dengan frekuensi penyiangan terhadap bobot segar tanaman, namun secara keseluruhan pemberian pupuk kandang sapi dengan 2 kali penyiangan memberikan hasil terbaik. Hal ini diduga ka rena pupuk kandang sapi dengan dosis 30 ton/Ha memberikan unsur hara yang cukup bagi tanaman selada. Penyiangan yang dilakukan juga diduga memberikan efek yang baik akibat turunnya persaingan antar tanaman.

\section{Bobot Segar Tanaman Per Plot}

Tabel 4 menunjukan bahwa tidak terjadi interaksi terhadap parameter bobot tanaman per plot, namun secara mandiri terdapat perbedaan nyata pada kedua perlakuan.

Tabel 4. Bobot Segar Tanaman

\begin{tabular}{llcc}
\hline \multicolumn{2}{l}{ PERLAKUAN } & $\begin{array}{c}\text { Bobot Segar Tanaman } \\
(\mathrm{gr})\end{array}$ & $\begin{array}{c}\text { Bobot Segar Tanaman } \\
\text { per Plot }(\mathrm{kg})\end{array}$ \\
\hline $\mathrm{k}_{0}$ & Pupuk NPK & $114,71 \mathrm{a}$ & $2,184 \mathrm{a}$ \\
$\mathrm{k}_{1}$ & Pupuk Kandang Kambing & $213,71 \mathrm{~b}$ & $4,204 \mathrm{~b}$ \\
$\mathrm{k}_{2}$ & Pupuk Kandang Sapi & $350,60 \mathrm{c}$ & $6,854 \mathrm{c}$ \\
$\mathrm{k}_{3}$ & Pupuk Kandang Ayam & $135,82 \mathrm{a}$ & $2,373 \mathrm{a}$ \\
\hline $\mathrm{p}_{0}$ & Tanpa Penyiangan & $171,80 \mathrm{a}$ & $3,228 \mathrm{a}$ \\
$\mathrm{p}_{1}$ & 2 kali Penyiangan & $240,13 \mathrm{~b}$ & $4,653 \mathrm{~b}$ \\
$\mathrm{p}_{2}$ & 4 kali Penyiangan & $199,20 \mathrm{ab}$ & $3,830 \mathrm{ab}$ \\
\hline
\end{tabular}

Keterangan: Angka yang diikuti huruf yang sama tidak berbeda nyata menurut uji DMRT taraf $5 \%$. 
Pada perlakuan pupuk kandang sapi, tanah plot percobaan relatif lebih lembap dibanding perlakuan lainnya, hal ini berpengaruh terhadap besar tulang daun yang akan memengaruhi bobot segar tanaman mengingat bahwa terdapat 94\% air dalam tanaman selada (USDA, 2019). Maka semakin banyak air yang diserap oleh tanaman semakin besar bobot segar tanaman selada.

Pupuk kandang sapi dapat meningkatkan kemampuan tanah untuk menyimpan air yang akan berfungsi untuk mengubah bahan organik menjadi unsur hara yang dapat langsung digunakan oleh tanaman selama masa pertumbuhannya (Trisnadewi dkk., 2012). Berbeda dengan tanah pada plot perlakuan pupuk kandang ayam yang relatif kering. Hal ini dapat disebabkan oleh banyaknya sekam yang tercampur pada pupuk kandang ayam sesuai dengan pernyataan Ashraf dan Junita (2020), bahwa media yang dicampur dengan sekam memiliki sifat porositas tinggi.

\section{Bobot Kering Tanaman}

Hasil analisis ragam pada tabel 5 menunjukkan terjadi interaksi antara jenis pupuk kandang dan frekuensi penyiangan pada parameter bobot kering tanaman. Hal ini diduga bahwa kebutuhan nutrisi tercukupi dan metabolism tananaman berjalan baik serta persaingan antara tanaman selada dan gulma pada periode kritis tanaman dapat ditekan.

Tabel 5. Berat Kering Tanaman (gram)

\begin{tabular}{cccc}
\hline \multirow{2}{*}{ Jenis Pupuk Kandang } & \multicolumn{3}{c}{ Frekuensi Penyiangan } \\
\cline { 2 - 4 } & $\mathrm{p}_{0}$ & $\mathrm{p}_{1}$ & $\mathrm{p}_{2}$ \\
& (Tanpa Penyiangan) & (2 kali Penyiangan) & (4 kali Penyiangan) \\
\hline $\mathrm{k}_{0}$ (Pupuk NPK) & $5,83 \mathrm{a}$ & $11,77 \mathrm{a}$ & $11,70 \mathrm{a}$ \\
$\mathrm{k}_{1}$ (Pupuk Kandang & $\mathrm{A}$ & $\mathrm{A}$ & $\mathrm{A}$ \\
Kambing) & $10,80 \mathrm{a}$ & $22,37 \mathrm{~b}$ & $11,57 \mathrm{a}$ \\
$\mathrm{k}_{2}$ (Pupuk Kandang & $\mathrm{A}$ & $\mathrm{B}$ & $\mathrm{A}$ \\
Sapi) & $24,27 \mathrm{~b}$ & $41,67 \mathrm{c}$ & $24,57 \mathrm{~b}$ \\
$\mathrm{k}_{3}$ (Pupuk Kandang & $\mathrm{A}$ & $\mathrm{B}$ & $\mathrm{A}$ \\
Ayam) & $9,87 \mathrm{a}$ & $12,60 \mathrm{a}$ & $10,87 \mathrm{a}$ \\
\hline
\end{tabular}

Keterangan: Angka rata-rata yang diikuti huruf kecil yang sama secara vertikal dan huruf besar yang sama secara horizontal tidak berbeda nyata menurut uji DMRT taraf $5 \%$

Secara keseluruhan kombinasi pupuk kandang sapi dengan dosis 30 ton/ha dengan 2 kali penyiangan memberikan hasil terbaik pada setiap parameter pengamatan. Bila dilihat dari nilai ketersediaan unsur $\mathrm{N}$ masing masing pupuk kandang yang relatif sama yaitu berkisar antara 0,5 $1 \%$ maka sangat memungkinkan bila terjadi keserupaan respon pertumbuhan tanaman terhadap perlakuan jenis pupuk kandang, namun hal ini tidak terjadi pada perlakuan pupuk kandang ayam 
yang memberikan hasil kurang begitu baik dibandingkan dengan pupuk kandang sapi dan kambing.

Hal ini diduga karena pada saat pengaplikasian pupuk kandang ayam masih dalam tahap pematangan. Pupuk kandang ayam termasuk kedalam jenis pupuk panas yaitu pupuk kandang yang dengan nilai $\mathrm{C} / \mathrm{N}$ ratio yang cukup rendah, pupuk ini mengalami proses dekomposisi yang cukup cepat sehingga terbentuk banyak gas yang menimbulkan pertambahan suhu pupuk. Pernyataan ini sesuai dengan pernyataan Novizan (2002), bahwa pupuk kandang ayam bersifat sebagai pupuk panas sehingga dekomposisi berlangsung secara cepat.

Pertumbuhan tanaman yang kurang baik dapat pula disebabkan oleh hama tanah yang ditemukan pada perlakuan pupuk kandang ayam, yang dapat mengganggu pertumbuhan tanaman. Hal ini sesuai dengan pernyataan Musnamar (2003) pupuk kandang sering menjadi faktor pembawa hama penyakit karena mengandung larva atau telur sehingga tanaman dapat diserang, kandungan unsur hara relatif rendah dibandingkan pupuk anorganik sehingga penggunaan dosisnya lebih tinggi. Respon tanaman terhadap pupuk organik lebih lambat dibanding pupuk anorganik.

Penyiangan sebanyak 2 kali selama umur tanaman memberikan hasil terbaik, hal ini disebabkan karena penyiangan yang cukup dapat menghambat pertumbuhan gulma yang menjadi competitor dalam penyerapan unsur hara, air juga cahaya matahari. Namun penyiangan yang dilakukan secara berlebihan dapat mengganggu sistem perakaran tanaman yang akan menghambat penyerapan hara dan membuat pertumbuhan tanaman terganggu atau bahkan mati.

Penyiangan sebanyak 2 kali selama umur tanaman memberikan hasil terbaik, hal ini menunjukkan bahwa penyiangan tidak perlu dilakukan terus menerus dilihat dari penurunan hasil pada perlakuan 4 kali penyiangan karena persiangan utama antara tanaman dengan gulma terjadi saat periode kritis pertumbuhan tanaman. Periode kritis pertumbuhan tanaman adalah pada awal fase vegetatif seperti yang dikatakan oleh Zimdahl (2004) periode kritis tanaman terjadi pada $25 \%$ sampai $33 \%$ pertama dari siklus hidup tanaman. Penyiangan terus menerus dapat mengganggu perakaran tanaman yang dapat menghambat pertumbuhan tanaman.

Populasi gulma menentukan besarnya gangguan yang disebabkan oleh gulma tersebut. Semakin lama jangka waktu kehadiran gulma besama tanaman, maka akan semakin besar penurunan hasil akibat kompetisi yang terjadi. Sedangkan kompetisi yang terjadi selama umur tanaman akan berdampak pada penurunan hasil yang sangat tinggi (Sembodo, 2010).

\section{Kesimpulan}

Berdasarkan hasil penelitian yang telah dilakukan maka dapat ditarik kesimpulan sebagai berikut.

1. Terjadi interaksi antara perlakuan jenis pupuk kandang dengan frekuensi penyiangan pada parameter bobot kering dan luas daun tanaman selada. 
2. Kombinasi perlakuan terbaik untuk setiap parameter pengamatan yang meliputi tinggi tanaman, jumlah daun, bobot segar tanaman, bobot segar tanaman per plot, bobot kering dan luas daun adalah perlakuan pupuk kandang sapi dengan 2 kali penyiangan.

\section{Daftar Pustaka}

Abrianto, W. (2011). Mari Mengolah Limbah Darah Sapi dan Limbah RPH untuk Pakan Ikan dan Pupuk Tanaman. www.duniasapi.com (Diakses 11 Maret 2020).

Ashraf, A., \& Junita, D. (2020). Efektifitas Jenis Media Tanam Terhadap Perkecambahan Benih Kacang Tanah (Arachis hypogea L). Jurnal Agrotek Lestari, 6(1), 28-33.

Badan Pusat Statistik. (2017). Produksi Tanaman Selada di Indonesia Tahun 2015-2017.

Devani, M. D. (2012). Pengaruh Bahan dan Dosis Kompos Cair Terhadap Pertumbuhan Selada (Lactuca sativa). Jurnal Agroteknologi Universitas Jambi. Jambi, 1(1), 16-22

Hendrival, H., Wirda, Z., \& Azis, A. (2014). Periode kritis tanaman kedelai terhadap persaingan gulma. Jurnal Floratek, 9(1), 6-13.

Musnamar, E. I. (2003). Pupuk Organik. Seri Agriwawasan, Penebar Swadaya. Bogor.

Novizan, I. (2002). Petunjuk Pemupukan yang Efektif. AgroMedia Pustaka. Jakarta.

Sembodo, D. R. J. (2010). Gulma dan Pengelolaannya. Graha Ilmu. Yogyakarta.

Trisnadewi, A. A. A. S., Susila, T. G. O., \& Wijana, I. W. (2012). Pengaruh jenis dan dosis pupuk kandang terhadap pertumbuhan dan produksi jagung manis (Zea Mays Saccharata Sturt). Pastura, 1(2), 52-55.

U.S Department Of Agriculture. (2019). Nutrient Database Lettuce, Cos, or Romaine. http://fdc.nal.usda.gov. (Diakses 5 Maret 2020)

Wijaya, K. A. (2008). Nutrisi Tanaman Penentu Kualitas Hasil dan Resestensi Alami Tanaman. Prestasi Pustaka Pulisher. Jakarta.

Zimdahl, R. L. (2004). Definition of plant competition. Weed-Crop Competition: A Review, Second Edition. Ames, IA: Blackwell Publishing Professional 